\title{
Analysis of Linkages between Environmental Policy Instruments and Innovation: A Case Study of End-of-Life Vehicles Technologies in Japan
}

\author{
Rajeev Kumar Singh ${ }^{1}$, Helmut Yabar ${ }^{2}$, Rie Murakami-Suzuki ${ }^{3}$, Noriko Nozaki $^{1}$ \& Randeep Rakwal ${ }^{4}$ \\ ${ }^{1}$ Graduate School of Life and Environmental Sciences, University of Tsukuba, 1-1-1 Tennodai, Tsukuba, Ibaraki \\ 305-8577, Japan \\ ${ }^{2}$ Faculty of Life and Environmental Sciences, University of Tsukuba, 1-1-1 Tennodai, Tsukuba, Ibaraki 305-8572, \\ Japan \\ ${ }^{3}$ K.K. Satisfactory International, 3-12-8 Hacchobori, Chuo-ku, Tokyo, 104-0032, Japan \\ ${ }^{4}$ Faculty of Health and Sport Sciences \& Tsukuba International Academy for Sport Studies (TIAS), University of \\ Tsukuba, 1-1-1 Tennodai, Tsukuba, Ibaraki 305-8574, Japan \\ Correspondence: Rajeev Kumar Singh, Graduate School of Life and Environmental Sciences, University of \\ Tsukuba, 1-1-1 Tennodai, Tsukuba, Ibaraki 305-8577, Japan. E-mail: tsukubaraj@gmail.com
}

Received: January 8, 2016 Accepted: February 1, 2016 Online Published: March 30, 2016

doi:10.5539/jsd.v9n2p181 URL: http://dx.doi.org/10.5539/jsd.v9n2p181

\begin{abstract}
Environmental policies are designed to deal with externalities either by internalizing environmental costs or imposing specific standards for environmental pollution. This study aims to examine the impact of environmental regulations related to End-of-Life Vehicles (ELV) on innovation in Japan. We determined whether there is any statistical difference in patent activity comparing the periods before and after the regulations were enacted. In order to control for exogenous factors such as business cycles, we also analyzed the ratios of ELV and total environmental patents during the same periods. Results showed that environmental regulations drive innovations and the number of ELV-related patents were larger even after controlling for such exogenous factors. We concluded that environmental policy for ELV in Japan was effective in inducing innovation. However, we also found that the weakness in these types of command and control policy is the lack of incentives for further innovation.
\end{abstract}

Keywords: environmental policy instruments, environmental innovations, end-of-life vehicles, Japan, patent data, statistical analysis

\section{Introduction}

Economic analysis of environmental policy asserts that the negative impact of economic activities on the environment constitutes an externality. To internalize such externalities and persuade firms to innovate with social optimum, environmental regulations are implemented (Johnstone et al., 2010). In general, environmental regulations aim at reducing the environmental impacts by setting specific conditions. These regulations will eventually trigger innovations as stated by the Porter hypothesis (Ambec et al., 2011). The environmental regulations can either be based on market mechanisms or command-and-control (CAC) approaches. The market-based instruments are mechanisms that are influenced by market signals rather than directives. Market-based regulations are limited by cost allowing firms to choose the least-cost solutions to improve environmental performances (Popp, 2010). The CAC regulations are considered to force the adoption of technology compared to market-based regulation (Lee et al., 2007). Further, CAC regulation also allows the firms to meet regulation standards or objectives using any technology. However, once the firms have reached a particular standard or objective using different technologies, there is little incentive for them to develop new technologies and/or to innovate. Therefore, firms stop investing in the research and development (R\&D) including technological development, which in turn decrease innovation (Jaffe et al., 2003).

There has been empirical evidence on induced innovation by regulation in the field of pollution abatement technologies and energy conservation technologies. Newell et al. (1999) examined appliance characteristics and 
energy prices to show that energy prices and regulatory standards affect the energy-efficiency innovation. Likewise, Popp (2006) studied patents from the United States, Japan, and Germany related to sulfur dioxide and nitrogen oxides, and showed there was a significant increase in patents related to sulfur dioxide and nitrogen oxides emissions reduction due to different environmental regulations in these countries. In contrast, some studies found no significant impact of the environmental regulations on innovation (Fischer et al., 2003). Most of the studies are based on finding the relation between market-based instruments and innovation. There are only few studies that have focused on finding the impact of command and control policies. Furthermore, there is limited research on exploring the relationship between innovation and environmental regulation on recycling and waste management. Yabar et al. (2012), for example, found that environmental regulations induce technological innovation in dioxin emissions from incinerators and recycling of home electric appliances in Japan. They used technological patents related to dioxin emissions and home appliances as a proxy in their study and found that environmental regulation triggers innovation. In this research, the End-of-Life Vehicles (ELV) patents were used as a proxy to find the relation between the ELV policies and innovations in Japan.

We determined whether there is any statistical difference in patent activity comparing the periods before and after the regulations were enacted using the patent data. The relevant Japanese data on ELV was gathered for the period 1990-2013 and the period was divided into: 1990-2001, 2002-2005 and 2006-2013 sub-periods. In order to control for exogenous factors such as business cycles, we also analyzed the ratios of ELV and total environmental patents during the same period.

\section{Japanese Environmental Regulations}

\subsection{Sound Material-Cycle Society in Japan}

In the 1950s and 1960s, due to rapid economic growth and rapid urbanization, there was a huge increase in waste volume and pollution of the environment due to inappropriate management of waste (Singh et al., 2015). To combat this problem, the Waste Management and Public Cleansing Law of 1970 focused on treatment of huge volumes of waste in a short period using facilities such as incinerators. This led to an increase in the number of batch-type incinerators in the 1970s. In the 1980s, lifestyle changes reflected a change in the nature of the waste such as an increase in plastic products and products with plastic packaging. The huge increase in plastic waste going for incineration was associated with dioxin emission ultimately giving rise to dioxin-related public health issues in the early 1990s. Studies revealed that there was extensive emission of dioxin in low-combustion and batch-type incinerators (Bagnati et al., 1990; Ohta et al., 1997). This pushed the government to introduce the Law Concerning Special Measures against Dioxins in 1999 (Law No. 105 of 1999). This facilitated the replacement of batch incinerators with continuous-type incinerators with dioxin-trapping technologies. Due to limited landfill space in Japan, the government focused on effective uses of resources and minimizing the environmental and health impacts on the whole life cycle of the products from the early 1990s (Yabar et al., 2012). This helped to promote not only the recycling of plastics but also of other valuable material from the waste stream that can be used as a source of raw materials. Many laws were made based on the $3 \mathrm{R}$ approach, i.e. Containers and Packaging Recycling Law (1995), Home Appliance Law (1998), Food Recycling Law (2000), and End-of-life Vehicles Recycling Law (2002) (Yabar et al., 2012; METI, 2004; METI, 2006). There are many studies on home appliance and ELV in Japan, but only a few studies have put their focus on proving that regulations drive innovation.

ELV is considered as a municipal waste in Japan (Fig. 1) and comprises around $10 \%$ of total municipal waste generation. Since local governments had concerns on the treatment and disposal of ELV, the central government introduced the ELV Recycling Law in 2002. 


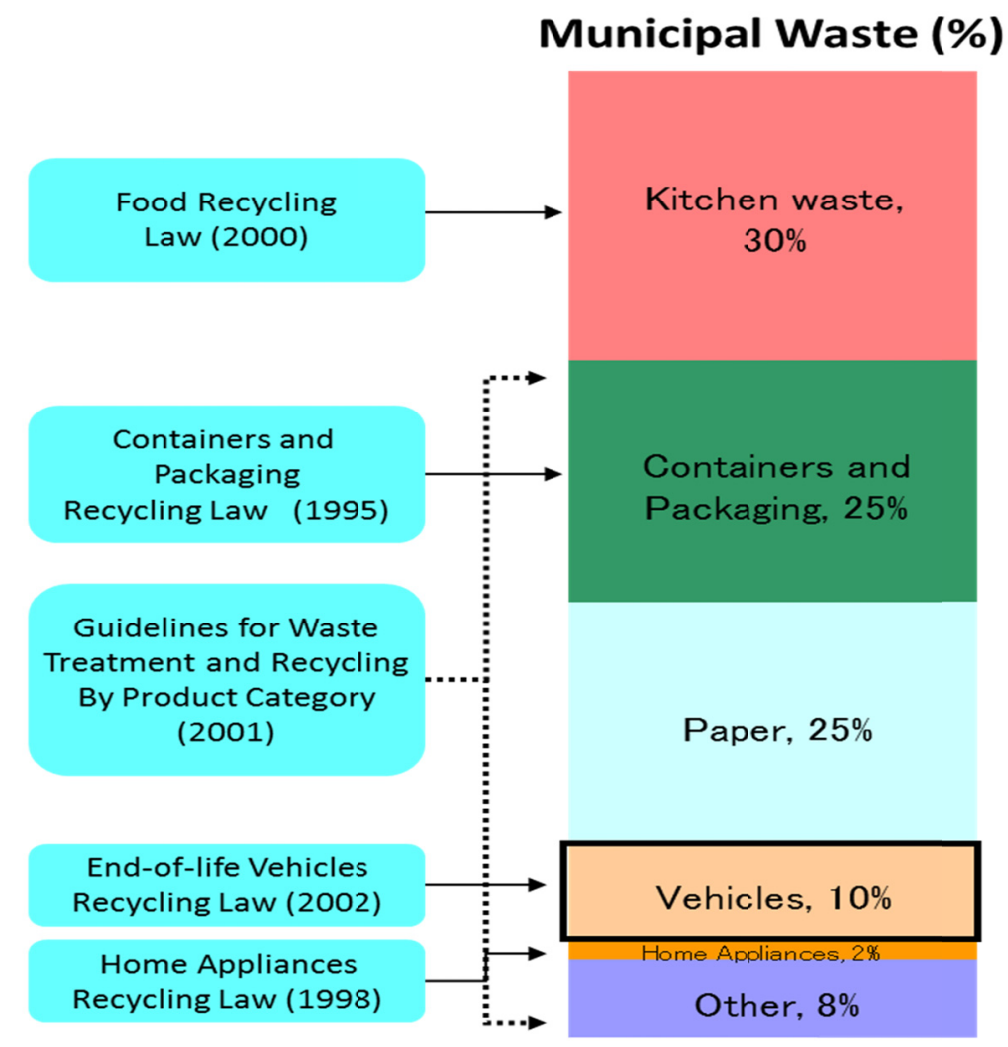

Figure 1. Composition of municipal waste in Japan (METI, 2004)

\subsection{Recycling Measures for End-of-Life Vehicles}

The ELV Recycling Law was passed in 2002, partially enforced in 2003 and fully enforced in 2005 with recovery and recycling of a) fluorocarbons, b) airbags, and c) automobile shredder residue (ASR). The target for airbag recycling was set $85 \%$ from 2005 onwards and the target for ASR was set at $30 \%$ by $2005,50 \%$ by 2010 and $70 \%$ by 2015 . Airbag recycling reached $93.4 \%$ and $93.8 \%$ in 2005 and 2014, respectively. The ASR recycling target was surpassed with $62.8 \%$ in $2005,82.5 \%$ in 2010 and $97.5 \%$ in 2014 due to the advancement and development in automobile design and improvement in the recycling efficiency of ASR (JARC, 2015).

The illegal dumping of waste including waste from automobiles on Teshima Island in Kagawa prefecture of Japan forced the government to revise the Waste Management and Public Cleansing Law in 1994 (Takatsuki, 2003). Prior to this, the ASR was thrown into inert landfill sites but after revision of the law it has been made compulsory to throw ASR into controlled landfill sites since 1996. The management cost of the controlled landfill sites is more expensive than the inert landfill sites. As a result, the manufacturers wanted to reduce the ASR volume and lower the treatment cost, which also contributed to innovation and a drastic reduction in the ASR. Furthermore, the Japanese Automobile Manufacturers Association (JAMA) set a target to reduce the total auto plant-generated waste going to landfill from 352,000 tons in 1990 as the base year to 10,000 tons by 2015 (JAMA, 2014). They surpassed this target in 2005 and reached 1,300 tons by 2011 (JAMA, 2014). 


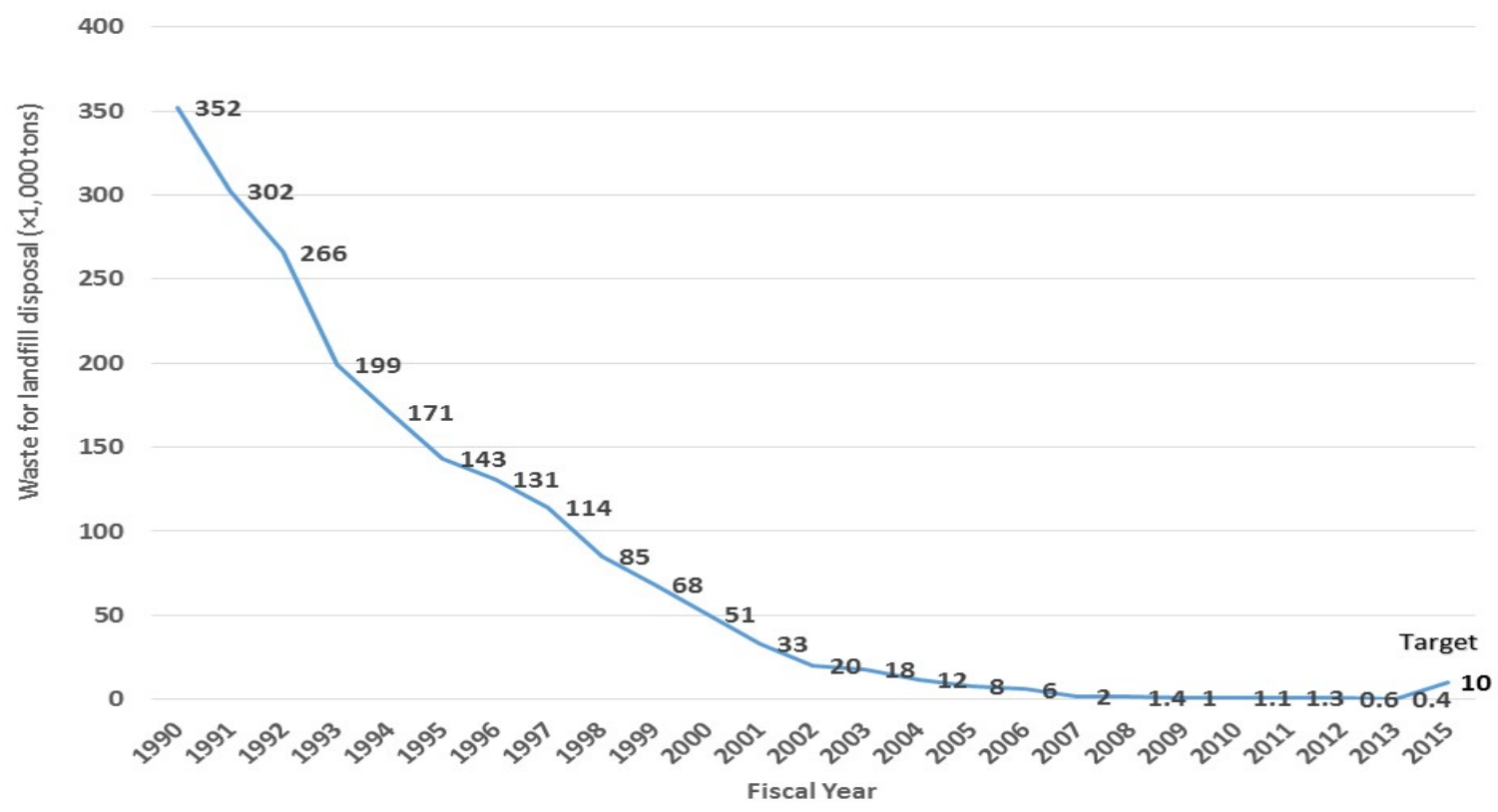

Figure 2. Amount of auto plant-generated waste going to landfill (JAMA, 2014)

\section{Patent Data as a Proxy to Measure Environmental Innovation}

The patent data related to ELV was used as a proxy to examine the link and effect of environmental policy on technological innovation for ELV. In the past, few empirical studies investigated the linkage between environmental policy and innovation due to a lack of patent data availability (Popp, 2005). Now due to more and free availability of patent data, we know that its use has many advantages (Popp, 2005; Yabar et al., 2012), which are as follows:

- Patent classification provides valuable information to find the advancement in a specific technology.

- The international patent system can be used to track the diffusion of technologies across countries.

- The rate of a given patent can display its potential for technological development and commercial value.

- Patent citations can help us ascertain the knowledge flow.

\section{Model Specification}

In order to determine whether ELV regulations are the major drivers of ELV innovation, we identified the relevant patents related to ELV recycling, mostly related to ASR, as shown in Table 1. These were identified using the World Intellectual Property Organization (WIPO) website and the Organization and Economic Cooperation and Development (OECD) Report for Total Environmental Patents (2011). We focused on the ASR technologies as the Japanese ELV regulation is much more concentrated on ASR. Furthermore, a Japanese patent database was used to find ELV patent counts. Specific codes were used for each ELV patents' group for simplicity during the statistical analysis. The PG1, PG2, PG3, PG4, PG5, PG6, PG7, PG8, PG9, PG10 and PG11 designations are the specific codes in which PG stands for Patent Group for different ELV patent groups as shown in order of Table 1. The capital letter B, D and A used in Table 2, Table 3 and Table 4 stands for before, during, and after the ELV regulation. 
Table 1. Patents related to ELV recycling technologies

\begin{tabular}{|c|c|c|}
\hline $\begin{array}{l}\text { Description of Patent/patents' } \\
\text { group }\end{array}$ & Patent IPC codes & $\begin{array}{l}\text { Assigned } \\
\text { Code }\end{array}$ \\
\hline Shredder dust treatment process & В03C1/00;B03B9/06;B09B5/00 & E1 \\
\hline $\begin{array}{l}\text { Process of chemical recycling of } \\
\text { polyurethane-containing scrap }\end{array}$ & C08G18/48;C08J11/24;C08G65/26;C08G18/83 & E2 \\
\hline $\begin{array}{l}\text { Method and plant for separating } \\
\text { polymeric materials }\end{array}$ & B29B17/02; B03B5/44; B03B5/28; B02C21/00; B03B9/06 & E3 \\
\hline $\begin{array}{l}\text { Unit and methods for processing } \\
\text { of shredder residues and uses of } \\
\text { sand fraction produced }\end{array}$ & $\begin{array}{l}\text { C22B1/00;B03B9/06;B02C23/14;C22B7/00;B03C1/00; B09B5/00;B09B3/00; B07B1/00; } \\
\text { В02C23/08; В07B9/00 }\end{array}$ & E4 \\
\hline $\begin{array}{l}\text { Unit and methods for the } \\
\text { treatment of shredder residues }\end{array}$ & $\begin{array}{l}\text { C22B7/00;B02C23/08;B02C23/14;B03B9/06;B07B4/08;C22B } \\
\text { 1/00;B09B5/00;B02C19/00 } \\
\text { В07B9/00;B29B17/02B03C1/00;B09B3/00 }\end{array}$ & E5 \\
\hline $\begin{array}{l}\text { System and method for treating } \\
\text { shredder residues }\end{array}$ & $\begin{array}{l}\text { В03B9/06;B02C23/08;B07B9/00;B09B5/00;C22B7/00;B09B3/00;B02C23/14;C22B1/00; } \\
\text { В03C1/00;B07B4/08;B29B17/02 }\end{array}$ & E6 \\
\hline $\begin{array}{l}\text { System and methods for sorting } \\
\text { recyclables at a material recovery } \\
\text { facility }\end{array}$ & $\begin{array}{l}\text { В07C5/00; B03B13/00;B07C5/342;B03B9/06; } \\
\text { В03B11/00 }\end{array}$ & E7 \\
\hline $\begin{array}{l}\text { Apparatus for selectively } \\
\text { separating polyurethane foam and } \\
\text { fiber from ASR }\end{array}$ & $\begin{array}{l}\text { B29L31/30;B29K75/00;B29K105/04;B03B } / 0 ; \\
\text { B29B17/02;B02C13/00;B02C23/14;B29B17/0;B09B3/00 }\end{array}$ & E8 \\
\hline Process for recycling old cars & $\begin{array}{l}\text { B01D53/14;C22B7/00;B03B9/06;B62D67/00; } \\
\text { B62D65/00;B09B3/00 }\end{array}$ & E9 \\
\hline $\begin{array}{l}\text { Presses specially adapted for } \\
\text { consolidating scrap metal or for } \\
\text { compacting used cars }\end{array}$ & B30B9/32 & E10 \\
\hline $\begin{array}{l}\text { Systematic disassembly of vehicles } \\
\text { for recovery of salvageable } \\
\text { components, e.g., for recycling }\end{array}$ & B62D67/00 & E11 \\
\hline
\end{tabular}

Source: WIPO

Figure 3 shows the registered patent count for the ELV-related technologies for the period 1990-2014. We used the key words specifically applied to ASR recycling technologies to find the most appropriate ELV-related technologies in our research. To avoid overlap in technologies, we used the ratios of ELV patents over the total environmental patents (see Appendix). The ELV recycling law was enacted in 2002, partially implemented in 2003, and fully implemented in 2005. In order to find out changes in the trend before, during, and after the ELV regulation period, we divided the period into: 1990-2001 (before regulation), 2002-2005 (during regulation) and 2006-2013 (after the first recycling target) periods. We then undertook t-test analysis using the SPSS software to analyze the statistical difference of ELV patents before and during the ELV regulation, and during and after the ELV regulation. Table 2 and Table 3 show the t-test results. To control the potential exogenous effects on factors and to prove that external factors were not involved in the ELV innovation, we determined the ratios of ELV patents over the total environmental patents and conducted t-test analysis for these ratios. 


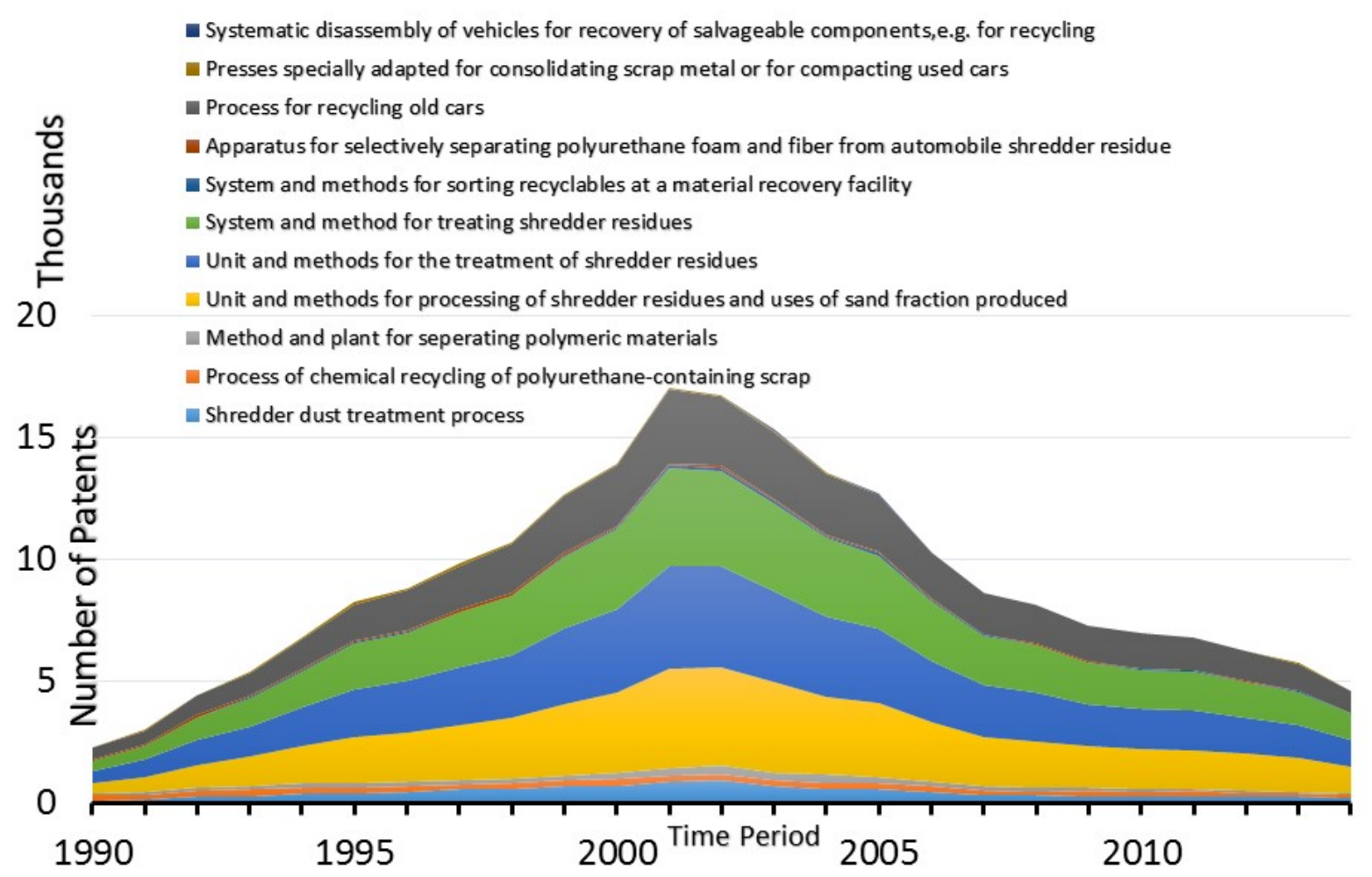

Figure 3. ELV recycling technological patent trends and policies

Table 2. Paired samples t-test results for group of patents before and during the ELV regulation

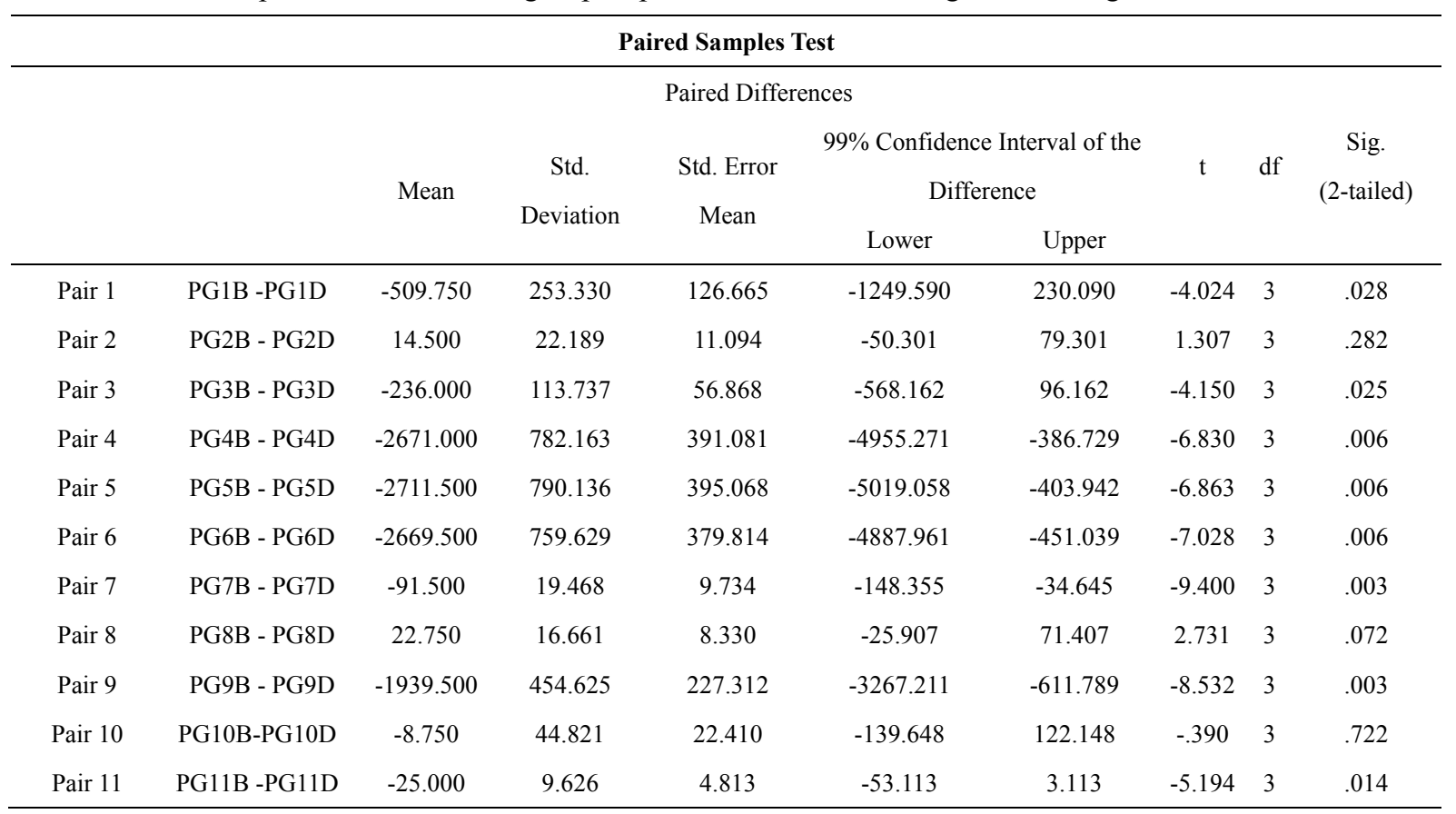


Table 3. Paired samples t-test results for group of patents during the ELV regulation and after the ELV recycling targets were met

\begin{tabular}{|c|c|c|c|c|c|c|c|c|c|}
\hline \multicolumn{10}{|c|}{ Paired Samples Test } \\
\hline \multicolumn{10}{|c|}{ Paired Differences } \\
\hline & & \multirow{2}{*}{ Mean } & \multirow{2}{*}{ Std. Deviation } & \multirow{2}{*}{ Std. Error Mean } & \multicolumn{2}{|c|}{$99 \%$ Confidence Interval of the Difference } & \multirow[t]{2}{*}{$\mathrm{t}$} & \multirow[t]{2}{*}{ df } & \multirow[t]{2}{*}{ Sig. (2-tailed) } \\
\hline & & & & & Lower & Upper & & & \\
\hline Pair 1 & PG1D - PG1A & 351.750 & 74.173 & 37.086 & 135.132 & 568.368 & 9.485 & 3 & .002 \\
\hline Pair 2 & PG2D - PG2A & 28.500 & 6.403 & 3.202 & 9.800 & 47.200 & 8.902 & 3 & .003 \\
\hline Pair 3 & PG3D - PG3A & 175.000 & 24.468 & 12.234 & 103.543 & 246.457 & 14.305 & 3 & .001 \\
\hline Pair 4 & PG4D - PG4A & 1468.500 & 185.272 & 92.636 & 927.422 & 2009.578 & 15.852 & 3 & .001 \\
\hline Pair 5 & PG5D - PGA & 1479.000 & 173.914 & 86.957 & 971.093 & 1986.907 & 17.008 & 3 & .000 \\
\hline Pair 6 & PG6D - PG6A & 1424.250 & 164.039 & 82.020 & 945.180 & 1903.320 & 17.365 & 3 & .000 \\
\hline Pair 7 & PG7D - PG7A & 52.500 & 16.663 & 8.332 & 3.835 & 101.165 & 6.301 & 3 & .008 \\
\hline Pair 8 & PG8D - PG8A & 28.000 & 10.231 & 5.115 & -1.878 & 57.878 & 5.474 & 3 & .012 \\
\hline Pair 9 & PG9D - PG9A & 937.750 & 102.500 & 51.250 & 638.403 & 1237.097 & 18.298 & 3 & .000 \\
\hline Pair 10 & PG10D -PG10A & 28.500 & 6.608 & 3.304 & 9.201 & 47.799 & 8.626 & 3 & .003 \\
\hline Pair 11 & PG11D -PG11A & 17.500 & 7.000 & 3.500 & -2.943 & 37.943 & 5.000 & 3 & .015 \\
\hline
\end{tabular}

In the t-test of the group before and during the ELV regulation, there was a significant difference for the majority of the patents at a $99 \%$ confidence interval. The patents in pair 2 and pair 8 are related to the recycling of polyurethane, which is also used in home appliances such as refrigerators. Thus, it can be inferred that the technology for polyurethane was introduced after the application of the Home Appliance Law in 1998 due to the advancement in technology before the introduction of the ELV Recycling Law in 2002. Moreover, the t-test between the ELV technological patents during the regulation and after the targets were met, shows that the patent count was higher during the regulation period with significance at the $99 \%$ confidence interval. Therefore, we found that the number of ELV-related technological patents in general is larger than in the period before the regulation and after the regulation targets were met.

We compared the ratio of the ELV technology-related patents to the total environment-related patents in order to find if there were any effects caused by exogenous and other factors such as business cycles and demand changes. The ratio of ELV technological patents over the total environmental patents is shown in Figure 4.

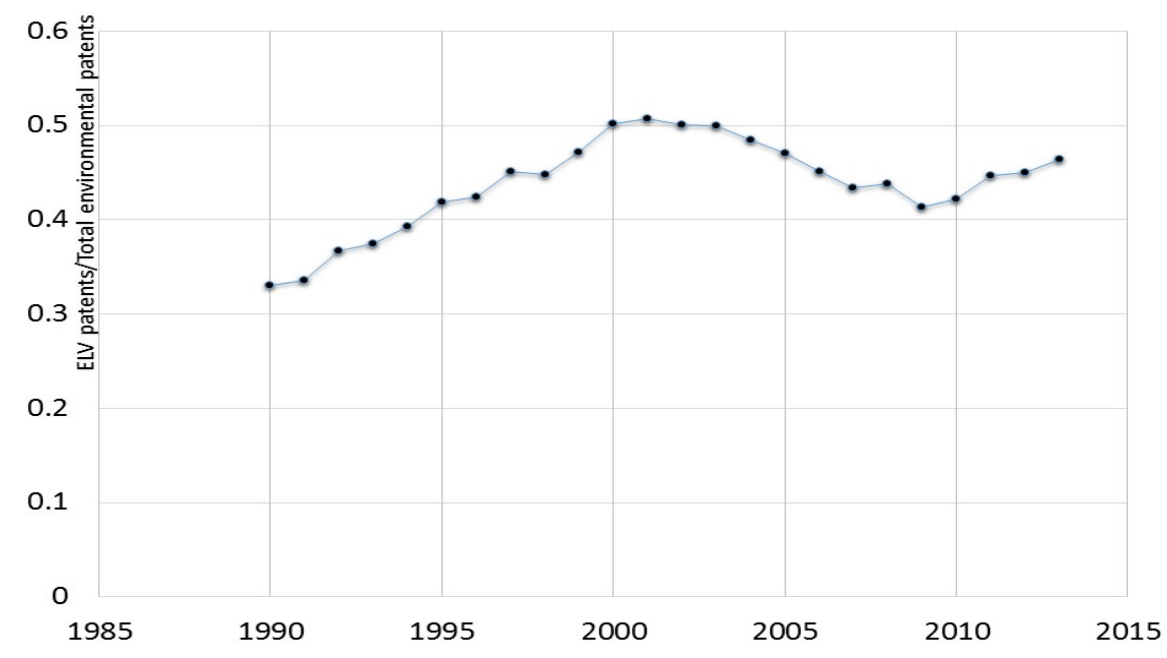

Figure 4. Ratio of ELV-related patents and total environmental patents 
The average ratio value of ELV technological patents and the total environmental patents before, during and after ELV regulation are shown in Figure 5.
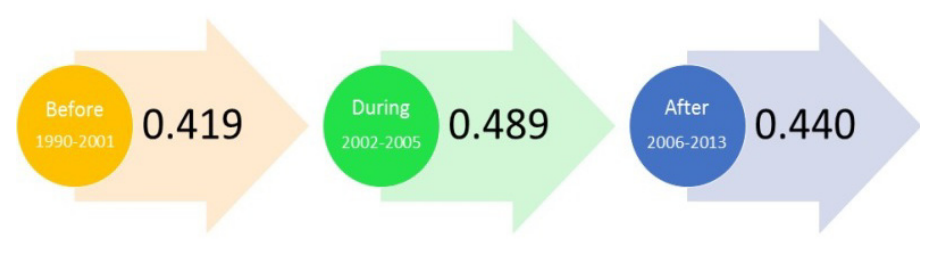

Figure 5. Average ratio value of ELV-related patents and total environmental patents before, during and after the ELV regulation

The ratio of ELV recycling patents to the total environmental patents before, during and after the ELV regulation was $0.419,0.489$ and 0.440 , respectively. This shows that ELV technological patents were higher during the regulation. Moreover, we again undertook a t-test of the ratio before, during, and after the regulation as shown in Table 4. The result shows that the ELV-related patents are higher during the regulation period compared to before and after the period, which demonstrates that the regulations were effective but once the regulation target is met, there is a decrease in ELV-related technological activities. The ratio before regulation, ratio during regulation and ratio after regulation in the table refer to the ratio of ELV recycling patents to the total environmental patents before, during, and after the ELV regulation, respectively.

Table 4. T-test of patents ratio before-during and during-after the regulation period

\begin{tabular}{|c|c|c|c|c|c|c|c|c|c|}
\hline \multicolumn{10}{|c|}{ Paired Samples Test } \\
\hline \multicolumn{10}{|c|}{ Paired Differences } \\
\hline & & \multirow[t]{2}{*}{ Mean } & \multirow{2}{*}{$\begin{array}{c}\text { Std. } \\
\text { Deviation }\end{array}$} & \multirow{2}{*}{$\begin{array}{c}\text { Std. Error } \\
\text { Mean }\end{array}$} & \multicolumn{2}{|c|}{$\begin{array}{l}95 \% \text { Confidence Interval of the } \\
\text { Difference }\end{array}$} & \multirow[t]{2}{*}{$\mathrm{t}$} & \multirow[t]{2}{*}{$\mathrm{df}$} & \multirow[t]{2}{*}{ Sig. (2-tailed) } \\
\hline & & & & & Lower & Upper & & & \\
\hline Pair 1 & $\begin{array}{l}\text { RatioB - } \\
\text { RatioD }\end{array}$ & -.13736 & .03639 & .01819 & -.19526 & -.07946 & -7.550 & 3 & .005 \\
\hline Pair 2 & $\begin{array}{l}\text { RatioD - } \\
\text { RatioA }\end{array}$ & .05486 & .00844 & .00422 & .04143 & .06830 & 12.998 & 3 & .001 \\
\hline
\end{tabular}

\section{Discussion and Conclusion}

This study analyzed the potential impact of environmental regulations on ELV recycling innovations in Japan. The statistical results show that the number of related patents to ELV recycling is larger during the ELV regulation period as compared to before and after the regulation. The result indicates that the ELV regulations were effective but once the targets were met, innovation slows due to a lack of incentives for further innovation. The recycling target and policy set by the Japanese government as environmental policy for automobiles push the auto industries to facilitate innovation mostly in the ASR sector. Moreover, it illustrates that proper regulation can activate advancement in environmental technologies through innovation, but after the targets are met, there is less incentive for the manufacturers to work towards further innovation. In this study, we used registered ELV patent data as a proxy for actual innovation. In the next stage of our study, we will use the FP2 patents (patents which are registered in more than two patent offices), which might provide us a more reliable result of valuable innovations. Further, we will explore the impact of not only patents but Research and Development (R\&D) data related to ELV innovation for stronger evidence.

\section{Acknowledgements}

We acknowledge Dr. Devena Haggis for her contribution in enhancing the quality of this paper. 


\section{References}

Ambec, S., Cohen, M., Elgie, S., \& Lanoie, P. (2011). The Porter Hypothesis at 20: Can Environmental Regulation Enhance Innovation and Competitiveness? SSRN Electronic Journal. http://dx.doi.org/10.2139/ssrn.1754674

Bagnati, R., Benfenati, E., Mariani, G., Fanelli, R., Chiesa, G., Moro, G., \& Pitea, D. (1990). The combustion of municipal solid waste and PCDD and PCDF emissions. On the real scale thermal behavior of PCDD and PCDF in flue gas and fly ash. Chemosphere, 20(10), 1907-1914.

Fischer, C., Parry, I. W. H., \& Pizer, W. A. (2003). Instrument choice for environmental protection when technological innovation is endogenous. Journal of Environmental Economics and Management, 45(3), 523-545.

Jaffe, A. B., Newell, R. G., \& Stavins, R. N. (2003). Technological change and the Environment. Handbook of Environmental Economics, 1, 461-516.

JAMA. (2014). 2014 Report on Environmental Protection Efforts: Promoting Sustainability in Road Transport in Japan. Retrieved from http://www.jama-english.jp/publications/env_prot_report_2014.pdf

JARC. (2015). JARC Data Book. Retrieved from http://www.jarc.or.jp/documents/databook.html

Johnstone, N., Hascic, I., \& Kalamova, M. (2010). Environmental Policy Characteristics and Technological $\begin{array}{llll}\text { Innovation. } & \text { Economia 275-299. }\end{array}$ http://www.oecd.org/env/consumption-innovation/48097418.pdf

Lee, J., Veloso, F. M., \& Hounshell, D. A. (2007). Innovation and Technology Policy: Lessons from Emission Control and Safety Technologies in the U.S. Automobile Industry. Working Draft prepared for the 2007 Sloan Industry Studies Conference.

Ministry of Economy, Trade and Industry. (2004). Handbook on Resource Recycling: Legislation and Trends in $3 R$. Retrieved from http://www.meti.go.jp/policy/recycle/main/data/pamphlet/pdf/cRecycle3R.pdf

Ministry of Economy, Trade and Industry. (2006). Global Economic Strategy: Summary. Retrieved from http://www.meti.go.jp/english/topic/downloadfiles/GlobalEconomicStrategy(Summary).pdf

Newell, R., Jaffe, A., \& Stavins, R. (1999). The induced innovation hypothesis and energy-saving technological change. The Quarterly Journal of Economics, 144(3), 941-975.

OECD. (2011). Invention and Transfer of Environmental Technologies. OECD Publishing 214-216.

Ohta, S., Kuriyama, S., Nakao, T., Aozasa, O., \& Miyata, H. (1997). Levels of PCDDs, PCDFs and non-ortho coplanar PCBs in soil collected from high cancer causing area close to batch-type municipal solid waste incineration in Japan. Organohalogen Compounds, 32, 155-160.

Popp, D. (2005). Lessons from patents: Using patents to measure technological change in environmental models. Ecological Economics, 54, 209-226.

Popp, D. (2006). International innovation and diffusion of air pollution control technologies: The effects of NOx and $\mathrm{SO}_{2}$ regulation in the U.S., Japan, and Germany. Journal of Environmental Economics and Management, 51(1), 46-71.

Popp, D. (2010). Energy, the Environment, and Technological Chance. Handbook of the Economics of Innovation, 2, 873-937.

Singh, R. K., Yabar, H., Nozaki, N., \& Rakwal, R. (2015). Analyzing Waste Problems in Developing Countries: Lessons for Kathmandu, Nepal through Analysis of the Waste System in Tsukuba City, Japan. Journal of Scientific Research \& Reports, 8(6), 1-13.

Takatsuki, H. (2003). The Teshima Island industrial waste case and its process towards resolution. Journal of Material Cycles and Waste Management, 5(1), 26-30. http://dx.doi.org/10.1007/s101630300005

WIPO. (n. d.). International Patent Classification (IPC) Official Publication. Retrieved from http://www.wipo.int/classifications/ipc/en/ITsupport/Version20100101/transformations/viewer/index.htm

Yabar, H., Uwasu, M., \& Hara, K. (2012). Tracking environmental innovations and policy regulations in Japan: case studies on dioxin emissions and electric home appliance recycling. Journal of Cleaner Production, 44, $152-158$. 


\section{Appendix}

The environmental patents used in this paper were selected from OECD (2011). The ELV recycling-related patent was selected using the WIPO website via key words related to ELV recycling and our own criteria specified in Table 1.

\section{Appendix: Patents related to Environmental Innovation}

\begin{tabular}{|c|c|}
\hline IPC codes & Description \\
\hline$B 01 D 46 / 00$ & Filters of filtering processes specially modified for separating dispersed particles from gases or vapours \\
\hline B01D47/00 & Separating dispersed particles from gases, air or vapours by liquid as separating agent \\
\hline B01D49/00 & Separating dispersed particles from gases, air or vapours by other methods \\
\hline$B 01 D 50 / 00$ & Combinations of devices for separating particles from gases or vapours \\
\hline B01D51/00 & Auxiliary pretreatment of gases or vapours to be cleaned from dispersed particles \\
\hline B03C3/00 & Separating dispersed particles from gases or vapour, e.g. air, by electrostatic effect \\
\hline C10L10/02 & Use of additives to fuels or fires for particular purposes for reducing smoke development \\
\hline C10L10/06 & Use of additives to fuels or fires for particular purposes for facilitating soot removal \\
\hline$C 21 B 7 / 22$ & Blast furnaces; dust arresters \\
\hline$C 21 C 5 / 38$ & $\begin{array}{l}\text { Manufacture of carbon steel, e.g. plain mild steel, medium carbon steel, or cast-steel; removal of waste gases or } \\
\text { dust }\end{array}$ \\
\hline$F 01 N 3 / 00$ & Exhaust or silencing apparatus having means for purifying or rendering innocuous \\
\hline F01N5/00 & Exhaust or silencing apparatus combined or associated with devices profiting by exhaust energy \\
\hline F01N7/00 & Exhaust or silencing apparatus, or parts thereof \\
\hline F01N9/00 & Electrical control of exhaust gas treating apparatus \\
\hline F01N11/00 & Monitoring or diagnostic devices for exhaust-gas treatment apparatus \\
\hline$F 23 B 80 / 00$ & $\begin{array}{l}\text { Combustion apparatus characterised by means for returning flue gases to the combustion chamber or to the } \\
\text { combustion zone }\end{array}$ \\
\hline$F 23 C 9 / 00$ & $\begin{array}{l}\text { Combustion apparatus characterised by arrangements for returning combustion products or flue gases to the } \\
\text { combustion chamber }\end{array}$ \\
\hline$F 23 J 15 / 00$ & Arrangements of devices for treating smoke or fumes of purifiers, e.g. for removing noxious material \\
\hline$F 27 B 1 / 18$ & Shaft or like vertical or substantially vertical furnaces; arrangements of dust collectors \\
\hline$F 23 G 7 / 06$ & Incinerators or other apparatus specially adapted for consuming waste gases or noxious gases \\
\hline B63J4/00 & Arrangements of installations for treating waste-water or sewage \\
\hline B01D53/34-36 & Chemical or biological purification of waste gases; by catalytic conversion \\
\hline B01D53/46-72 & Chemical or biological purification of waste gases; removing components of defined structure \\
\hline$C 05 F 7 / 00$ & Fertilisers from waste water, sewage sludge, sea slime, ooze or similar masses \\
\hline$C 09 K 3 / 32$ & Chemistry; materials for treating liquid pollutants, e.g. oil, gasoline, fat \\
\hline E02B15/04-06 & $\begin{array}{l}\text { Devices for cleaning or keeping clear the surface of open water from oil or like floating materials by separating } \\
\text { or removing these materials; barriers therefor/Cleaning or keeping clear the surface of open water; devices for } \\
\text { removing the material from the surface }\end{array}$ \\
\hline E03B3/00 & Methods or installations for obtaining or collecting drinking water or tap water; rain, surface or groundwater \\
\hline E03C1/12 & Plumbing installations for waste water \\
\hline$E 03 F / 00$ & Sewers - cesspools \\
\hline$C 05 F 7 / 00$ & Fertilisers from waste water, sewage sludge, sea slime, ooze or similar masses \\
\hline$A 23 K 1 / 06-10$ & $\begin{array}{l}\text { Animal feeding-stuffs from distillers' or brewers' waste; waste products of dairy plant; meat, fish, or bones; from } \\
\text { kitchen waste }\end{array}$ \\
\hline
\end{tabular}


A43B1/12 Footwear made of rubber waste

A43B21/14

A61L11/00

B03B9/06

B22F8/00

$B 27 B 33 / 20$

$B 29 B 17 / 00$

$B 29 B 7 / 66$

$B 30 B 9 / 32$

B62D67/00

B65H73/00

C04B7/24-30

C04B11/26

C04B18/04-10

C04B33/132

C05F9/00

C08J11/00

C09K11/01

C10G1/10

C10L5/46-48

C10M175/00

$C 22 B 7 / 00$

C22B19/28-30

$C 22 B 25 / 06$

D01B5/08

D01G11/00

D01G19/22

D21B1/08

$D 21 B 1 / 32$

D21C5/02

D21H17/01

E01H6/00

E01H15/00

F23G5/00

$F 23 G 7 / 00$

G08B21/00

Heels or top-pieces made of rubber waste

Medical or veterinary science; disinfection or sterilising methods specially adapted for refuse

Separating solid materials; general arrangement of separating plant specially adapted for refuse

Manufacture of articles from scrap or waste metal particles B22F8

Sawing tools for saw mills, sawing machines, or sawing devices; edge trimming saw blades or tools combined with means to disintegrate waste

Recovery of plastics or other constituents of waste material containing plastics

Preparing material; recycling the material

Presses specially adapted for consolidating scrap metal or for compacting used cars

Systematic disassembly of vehicles for recovery of salvageable components, e.g. for recycling

Stripping waste material from cores or formers, e.g. to permit their re-use

Hydraulic cements from oil shales, residues or waste other than slag

Calcium sulfate cements starting from phosphogypsum or from waste, e.g. purification products of smoke

Use of agglomerated or waste materials or refuse as fillers for mortars, concrete or artificial stone; waste materials or refuse

Clay-wares; waste materials or refuse

Fertilisers from household or town refuse

Recovery or working-up of waste materials

Luminescent, e.g. electroluminescent, chemiluminescent, materials; recovery of luminescent materials

Production of liquid hydrocarbon mixtures from rubber or rubber waste

Solid fuels essentially based on materials of non-mineral origin; on sewage, house, or town refuse; on industrial residues or waste materials

Working-up used lubricants to recover useful products

Working-up raw materials other than ores, e.g. scrap, to produce non-ferrous metals or compounds thereof

Obtaining zinc or zinc oxide; from muffle furnace residues; from metallic residues or scraps

Obtaining tin; from scrap, especially tin scrap

Mechanical treatment of natural fibrous or filamentary material to obtain fibres or filament; arrangements for removing or disposing of, tow or waste

Textiles; disintegrating fibre-containing articles to obtain fibres for re-use

Textiles; arrangements for removing, or disposing of, noil or waste

Paper-making; fibrous raw materials or their mechanical treatment; the raw material being waste paper or rags Paper-making; fibrous raw materials or their mechanical treatment; defibrating by other means of waste paper Paper-making; other processes for obtaining cellulose; working-up waste paper

Paper-making; pulping; non-fibrous material added to the pulp; waste products

Street cleaning; apparatus equipped with, or having provisions for equipping with, both elements for removal of refuse or the like and elements for removal of snow or ice

Street cleaning; removing undesirable matter, e.g. rubbish, from the land, not otherwise provided for

Cremation furnaces; incineration of waste; incinerator constructions; details, accessories or control therefor

Cremation furnaces; incinerators or other apparatus specially adapted for consuming specific waste or low grade fuels

Alarms responsive to a single specified undesired or abnormal condition and not otherwise provided for, e.g. pollution alarms; toxics 


$\begin{array}{ll}C 02 F & \text { Treatment of water, waste. sewage or sludge } \\ B 09 B & \text { Disposal of solid waste } \\ \text { B09C } & \text { Reclamation of contaminated soil } \\ \text { B65F } & \text { Transporting; gathering or removal of domestic or like refuse }\end{array}$

\section{Copyrights}

Copyright for this article is retained by the author(s), with first publication rights granted to the journal.

This is an open-access article distributed under the terms and conditions of the Creative Commons Attribution license (http://creativecommons.org/licenses/by/3.0/). 